\title{
CEP290 is required for photoreceptor ciliogenesis and other cilia related functions
}

\author{
RA Rachel ${ }^{1 *}$, EA Yamamoto ${ }^{1}$, M Dewanjee ${ }^{1}$, J Munasinghe ${ }^{2}$, HL May-Simera', L Dong ${ }^{1}$, A Swaroop ${ }^{1}$ \\ From First International Cilia in Development and Disease Scientific Conference (2012) \\ London, UK. 16-18 May 2012
}

Mutations in CEP290, which encodes a centrosomal/ cilia protein, result in a broad range of human ciliopathies from isolated Leber congenital amaurosis to lethal Meckel-Gruber syndrome. By light microscopy, CEP290 localizes to the ependymal cells lining the lateral ventricles, to respiratory airways, and to ciliated cells of the kidney. By immunoEM in photoreceptors, CEP290 localizes to ciliary microtubules of the connecting cilium. We generated a null allele of Cep290 in mice by replacing exons 1-4 of the Cep290 gene with a lacZ-neo cassette and analyzed Cep290-knockout mouse phenotypes. Cep290ko/ko mice develop hydrocephalus and most (80$100 \%$, strain-dependent) die by one month. Both C57BL/ 6 and 129SvJ backgrounds reduce viability of Cep290ko/ $k o$ mice. High-resolution MRI of the brain demonstrates enlarged ventricles and other morphological abnormalities. By SEM ependymal cells in the Cep290ko/ko mice have reduced numbers of unorganized cilia, in contrast to the tufts of cilia lining the WT ventricular epithelium. Knockout mice having subclinical hydrocephalus survive and reproduce normally. Photoreceptors fail to generate connecting cilia or outer segments in Cep290ko/ko mice, although basal bodies and associated microtubule assemblies are found. The presence of basal bodies and microtubule rings without connecting cilia or outer segments indicates that CEP290 is essential for ciliogenesis in photoreceptors. Most photoreceptors die between P14 and P28. Cep290ko/+ mice do not have retinal degeneration or hydrocephalus, demonstrating haplosufficiency. Our results indicate that CEP290 plays a critical role in ciliogenesis and cilia function in subsets of neurons and have begun to shed light on underlying mechanisms in ciliopathies.

* Correspondence: rachelr@nei.nih.gov

${ }^{1} \mathrm{NIH} /$ National Eye Institute, USA

Full list of author information is available at the end of the article
Author details

${ }^{1} \mathrm{NIH} /$ National Eye Institute, USA. ${ }^{2} \mathrm{NIH} /$ Neurological Diseases \& Stroke, USA.

Published: 16 November 2012

doi:10.1186/2046-2530-1-S1-P98

Cite this article as: Rachel et al:: CEP290 is required for photoreceptor ciliogenesis and other cilia related functions. Cilia 2012 1(Suppl 1):P98.

Submit your next manuscript to BioMed Central and take full advantage of:

- Convenient online submission

- Thorough peer review

- No space constraints or color figure charges

- Immediate publication on acceptance

- Inclusion in PubMed, CAS, Scopus and Google Scholar

- Research which is freely available for redistribution 